Tersedia online di: http://ejournal-balitbang.kkp.go.id/index.php/bawal
e-mail:bawal.puslitbangkan@gmail.com
BAWAL wIDYA RISET PERIKANAN TANGKAP
Volume 11 Nomor 1 April 2019
p-ISSN: 1907-8226
e-ISSN: 2502-6410
BAWAL
Nomor Akreditasi Kementerian RISTEKDIKTI: 21/E/KPT/2018

\title{
PARAMETER POPULASI IKAN \\ KERAPU KARANG BINTIK BIRU (Cephalopholis cyanostigma, Valenciennes, 1828) DI PERAIRAN KARIMUNJAWA, JAWA TENGAH
}

\author{
POPULATION PARAMETERS OF BLUESPOTTED HIND \\ (Cephalopholis cyanostigma, Valenciennes, 1828) \\ IN KARIMUNJAWA WATERS, CENTRAL JAVA
}

\begin{abstract}
Prihatiningsih $^{* 1}$, Isa Nagib Edrus ${ }^{1}$ dan Sri Turni Hartati ${ }^{2}$
${ }^{1}$ Balai Riset Perikanan Laut, Cibinong, Bogor, Jl. Raya Bogor KM. 47 Cibinong, Bogor- Jawa Barat, Indonesia ${ }^{2}$ Pusat Riset Perikanan, Gedung BRSDM KP II, Jl. Pasir Putih II, Ancol Timur, Jakarta Utara 14430, Indonesia Teregistrasi I tanggal: 13 Februari 2017; Diterima setelah perbaikan tanggal: 06 Juni 2017; 11 Agustus 2017 Disetujui terbit tanggal: 22 Januari 2020
\end{abstract}

\begin{abstract}
ABSTRAK
Ikan kerapu karang bintik biru (Cephalopholis cyanostigma) merupakan kelompok ikan karang dari family Serranidae. Ikan ini dalam daftar merah IUCN versi 2016-3, termasuk spesies yang kurang perhatian (least concern). Ikan ini termasuk komoditas penting dan terus dieksploitasi. Dalam rangka penentuan pengelolaan perikanan yang baik diperlukan informasi dasar terkait dengan parameter populasi kerapu karang bintik biru di wilayah tersebut. Penelitian ini dilakukan pada tahun 2016 di Karimunjawa, Jawa Tengah untuk melakukan kajian parameter populasi. Metode yang digunakan adalah metode sampling secara acak dengan aplikasi model analitik yaitu model Gulland \& Holt plot. Hasil penelitian menunjukkan bahwa modus ukuran ikan kerapu karang bintik biru adalah $25 \mathrm{~cm}$ TL, dengan kisaran 15,6-38,9 cm TL. Persamaan pertumbuhan Von Bertalanffy untuk kerapu karang bintik biru adalah $\mathrm{L}_{\mathrm{t}}=37,29\left(1-\mathrm{e}^{-0,3(-1-0,0429)}\right)$. Rata-rata ukuran panjang pertama kali tertangkap $\left(\mathrm{L}_{\mathrm{c}}\right)$ lebih besar dari rata-rata ukuran panjang pertama kali matang gonad $\left(\mathrm{L}_{\mathrm{m}}\right)$. Tingkat kematian alami $(\mathrm{M}=0,78 /$ tahun) ikan C.cyanostigma lebih kecil dibandingkan dengan tingkat kematian karena aktivitas penangkapan ( $\mathrm{F}=0,99 /$ tahun) dan tingkat pemanfaatannya sebesar 0,56/tahun sehingga pengelolaan ikan kerapu karang bintik biru (C.cyanostigma) di Karimunjawa, Jawa Tengah sedikit melebihi optimum.
\end{abstract}

Kata Kunci: Cephalopholis cyanostigma; parameter populasi; Karimunjawa

\begin{abstract}
The bluespotted hind (Cephalopholis cyanostigma) is a group of coral fishes from the family Serranidae. The fish is in the IUCN Red List version 2016-3, including species that have least concern. This fish is an important commodity that is still being exploited. In order to determine the management of good fisheries, it is required basic information related to the parameters of the bluespotted hind population in the region. This research was conducted in Karimunjawa, Central Java based on data collected during period of survey in 2016. The purpose of this study was to reviewing the population parameters of bluespotted hind. This study used random sampling method and the analitycal model by the application of Gulland \& Holt plot. The results showed that the fish length mode of bluespotted hind was $25 \mathrm{~cm}$ TL, with a range of $15.6-38.9 \mathrm{~cm}$ TL. The growth equation of Von Bertalanffy for a bluespotted hind was $L t=37,29(1-E-0.3$ (T-0.0429)). The average fish length of first captured $\left(L_{c}\right)$ is greater than the average fish length of first maturity $\left(L_{m}\right)$. Natural mortality $(M=0.78 /$ year $)$ is smaller than the fishing mortality $\left(F=0.99 /\right.$ year). The exploitation ${ }^{\prime}$ rate was $0.56 /$ year indicates that the utilization rate of the bluespotted hind (C. Cyanostigma) in Karimun Jawa, Central Java slightly exceeds the optimum.
\end{abstract}

Keywords: Cephalopholis cyanostigma; population parameters; Karimunjawa

Korespondensi penulis:

e-mail:inedrus@yahoo.co.id,nining.bppl@gmail.com

Telp. +62 813-1756-0187

DOI: http://dx.doi.org/10.15578/bawal.11.1.2019.59-68

Copyright (C) 2019, BAWAL WIDYA RISET PERIKANAN TANGKAP (BAWAL) 


\section{PENDAHULUAN}

Kepulauan Karimunjawa ditetapkan sebagai Taman Nasional Karimunjawa (TNKJ) sejak 1999 dengan SK Menteri Kehutanan dan Perkebunan No. 78/Kpts-II/1999. Kemudian, tanggal 15-3-2001 ditetapkan sebagai Taman Nasional Laut melalui Kepmen Kehutanan No. 74/KptsII/2001 (Ruchimat et al., 2012). Pengelolaan Taman Nasional tersebut berdasarkan pada pola zonasi yang terdiri dari 7 zona pengelolaan. Zona Pemanfaatan Perikanan Tradisional seluas 103.883,86 ha, yaitu 93\% dari total luasan TNKJ (Irnawati et al., 2012). Ekosistem terumbu karang di Perairan Karimunjawa dan pesisir Jepara sebesar 7.353,68 ha (Bakosurtanal, 2009) memiliki potensi sumberdaya ikan yang perlu dikelola dengan baik.

Jenis-jenis ikan hasil tangkapan nelayan Karimunjawa secara umum dapat diklasifikasikan sebagai ikan karang yang memiliki tingkat assosiasi ekologis yang sangat kuat dengan terumbu karang. Hasil penelitian Mujiyanto \& Syam (2015) pada perairan karang Karimunjawa menunjukkan bahwa keberadaan ikan kerapu cenderung pada habitat koloni karang keras (hard coral) pada kedalaman \pm 10 -11 meter, terutama pada lokasi Pulau Menjangan Besar, Pulau Kumbang, Pulau Kecil dan Pulau Cemara Besar.

Hasil tangkapan menurut data statistik Pelabuhan Perikanan Pantai Karimunjawa (2016) menunjukkan bahwa komposisi kerapu balong dan kerapu karang bintik biru jauh lebih tinggi dibanding kerapu sunu, kerapu lumpur dan kerapu bebek. Produksi kerapu karang bintik biru dengan alat tangkap bubu dan panah pada 2014, 2015 sampai 2016 yang masing-masing sebesar $1.320 \mathrm{~kg}, 3.089$ $\mathrm{kg}$ dan $3.869 \mathrm{~kg}$ menunjukkan adanya peningkatan sebesar $66 \%$.

Kerapu karang bintik biru sering ditemukan di area perlindungan laut di dalam habitat yang termasuk rentang distribusinya, terutama wilayah yang terjaga oleh kegiatan konservasi. Di dalam beberapa wilayah, kerapu karang terlihat bermigrasi ke luar area perbatasan taman laut dan dapat ditangkap $50 \mathrm{~m}$ di luar batas area tersebut (Zeller et al., 2003). Sejauh ini tidak ada tindakan khusus yang spesifik untuk jenis kerapu ini, oleh karena itu jenis ini termasuk rentan pada kelebihan tangkap dan keberlangsungan hidupnya juga rentan karena kerusakan habitat (Cabanban et al., 2015). Kerapu karang bintik biru adalah jenis ikan karang yang bersifat cryptic, suka bersembunyi di sela karang sepanjang hari dan sangat bergantung pada struktur bangun karang (Bryce \& Beukers, 2000).

Kerapu karang bintik biru dianggap rawan dalam pemanfaatnya karena sebaran hidup dan pemanfaatnya sangat luas. Jenis ini juga sering ditemukan di sejumlah area perlindungan laut dan perairan karang tanpa pengelolaan yang baik. Jenis ini ditemukan dalam perdagangan ikan karang hidup untuk konsumsi. Degradasi habitat, kelimpahan rendah pada perairan karang dangkal, rentanitasnya pada kelebihan tangkap adalah bagian dari rentang permasalahan di atas. Untuk alasan ini pada 1 januari 2008, kerapu karang bintik biru dimasukkan dalam daftar merah IUCN dengan kategori dan kriteria "kurang perhatian" versi 3.1. (Choat et al., 2008).

Monitoring dan penelitian dapat menjamin pengelolaan jenis kerapu karang ini, tetapi untuk mengerjakan itu juga dibutuhkan masukan data tambahan (Cabanban et al., 2015). Informasi dasar terkait dengan biologi reproduksi dan parameter populasi kerapu karang diperlukan untuk penentuan kebijakan pengelolaan perikanan yang baik di wilayah perairan karang Laut Jawa. Tidak banyak penelitian yang sama dilakukan untuk jenis kerapu Karang bintik biru, seperti pernah dilakukan penelitian di The Autralian Great Barrier Reefs (Mosse, 2001).

Tujuan dari penelitian ini adalah mengkaji parameter populasi $\left(\mathrm{L}_{\mathrm{c}}, \mathrm{L}_{\mathrm{m}}, \mathrm{L}_{\infty}, \mathrm{K}, \mathrm{Z}, \mathrm{M}, \mathrm{F}\right.$, dan $\left.\mathrm{E}\right)$ jenis kerapu karang bintik biru yang ditangkap di Karimunjawa, sehingga dapat dijadikan sebagai bahan masukan dalam pengelolaan perikanan kerapu karang di perairan Utara Jawa.

\section{BAHANDANMETODE Pengumpulan Data}

Pengumpulan data dilakukan di tempat pengumpul ikan Karimunjawa pada Januari - Nopember 2016. Sampel ikan kerapu karang bintik biru diperoleh dari hasil tangkapan bubu dan panah. Sampel ikan diukur panjang total dengan mistar ketelitian $1 \mathrm{~mm}$ dan bobot ditimbang dengan timbangan $5 \mathrm{~kg}$ dan ketelitian $0.1 \mathrm{gram}$. Tingkat kematangan gonad diperiksa dari ikan sample. Jumlah sampel yang diambil untuk pengukuran panjang berat dan serta diperiksa gonadnya adalah 86 ekor. Adapun data ukuran panjang total yang merupakan hasil pencatatan enumerator, staf pegawai Pelabuhan Perikanan Pantai Karimunjawa, adalah 1.946 ekor.

\section{Analisis Data \\ Hubungan Panjang Berat}

Hubungan panjang dan berat ikan dapat ditentukan dengan menggunakan persamaan menurut Effendie (2002):

$W=a L^{b}$

dimana: $\mathrm{W}$ adalah berat (g) ikan dengan $\mathrm{L}$ adalah panjang ikan $(\mathrm{cm})$, a dan b adalah koefesien pertumbuhan berat. Selanjutnya dilakukan uji statistik (uji t) pada selang kepercayaan $95 \%$. 


\section{Pendugaan Rata-Rata Ukuran Panjang Pertama kali Tertangkap $\left(L_{c}\right)$.}

Penghitungan nilai $\mathrm{L}_{\mathrm{c}}$ diperoleh dari frekuensi kumulatif data panjang ikan yang diperkirakan pada posisi 50 persen populasinya dapat tertangkap dengan rumus (Jones, 1976 dalam Sparre \& Venema, 1999) :

$$
\begin{aligned}
& S_{L} \text { est }=\frac{1}{1+\exp \left(S_{1}-S_{2} * L\right)} \\
& \operatorname{Ln}\left[\frac{1}{S L}-1\right]=S_{1}-S_{2} * L, L_{50 \%}=\frac{S_{1}}{S_{2}}
\end{aligned}
$$

dimana;

$$
\begin{array}{ll}
\mathrm{SL} & =\text { kurva logistik } \\
\mathrm{S}_{1} & =\mathrm{a} \\
\mathrm{S}_{2} & =\mathrm{b} \\
\mathrm{S}_{1} \text { dan } \mathrm{S}_{2} & =\text { konstanta pada rumus kurva logistik }
\end{array}
$$

\section{Pendugaan Rata-Rata Panjang Pertama Kali Matang $\operatorname{Gonad}\left(L_{m}\right)$.}

Tingkat estimasi kematangan gonad diamati secara visual mengikuti skala kematangan gonad standar menurut kriteria Holden \& Raitt (1974) seperti pada Lampiran 1. Pendugaan rata-rata panjang pertama kali matang gonad (length at first maturity) dilakukan sesuai dengan prosedur penghitungan yang dilakukan Udupa (1986), melalui rumus :

$\mathrm{m}=\mathrm{Xk}+\mathrm{X} / 2-(\mathrm{X}$ pi $)$

dimana;

$\mathrm{m}$ : log ukuran ikan saat pertama matang ovarium

Xk : log ukuran ikan dimana 100\% ikan sampelsudah matang

$\mathrm{X}$ : selang log ukuran (log size increment)

$\mathrm{Pi}$ : proporsi ikan matang pada kelompok ke-i. Dan ratarata ukuran ikan pertama matang ovarium diperoleh dari nilai $\operatorname{antilog}(\mathrm{m})$.

\section{Estimasi Parameter Pertumbuhan}

Parameter pertumbuhan $\left(\mathrm{L}_{\infty}\right.$ dan $\left.\mathrm{K}\right)$ didasari melalui persamaan von Bertalanffy (Sparre \& Venema (1999) melalui persamaan:

$\mathrm{L}_{\mathrm{t}}=\mathrm{L}_{\infty}\left(1-\mathrm{e}^{-\mathrm{k}(\mathrm{t}-\mathrm{to})}\right)$

dimana :

Lt : ukuran panjang ikan pada saat umur $\mathrm{t}$ tahun $(\mathrm{cm})$;

$1_{\infty} \quad$ : panjang maksimum ikan yang dapat dicapai

$\mathrm{t}_{\mathrm{o}} \quad$ : umur ikan teoritis pada saat panjangnya $0 \mathrm{~cm}$

$\mathrm{k}$ : Koefisien pertumbuhan 0
Nilai dugaan umur teoritis pada saat panjang ikan sama dengan nol $\left(\mathrm{t}_{\mathrm{o}}\right)$ diperoleh melalui persamaan Pauly (1980) :

$\log -\left(t_{0}\right)=-0,3922-0,2752 \log \mathrm{L}-1,038 \log \mathrm{K}$

Kemudian dengan mengestimasi melalui metode Gulland \& Holt (1959) in Sparre \& Venema (1999), persamaan di atas diturunkan menjadi persamaan berikut: $\Delta L / \Delta t=K L \infty-K L t$

dengan menganggap $\Delta \mathrm{L} / \Delta \mathrm{t}$ sebagai $\mathrm{y} ; \mathrm{K} \mathrm{L}_{\infty}$ sebagai a dan K Lt sebagai b maka nilai $\mathrm{L}_{\infty}$ dapat diestimasi melalui persamaan :

$L \infty=-a / b$

dan nilai K diestimasi melalui persamaan :

$K=-b$

\section{Perhitungan Laju Kematian dan Laju Eksploitasi}

Pendugaan mortalitas alami (=M) diduga dengan menggunakan persamaan empiris dari Pauly (1980) dalam Sparre \& Venema (1999), yaitu menggunakan masukan data suhu perairan rata-rata $\left(=\mathrm{T},{ }^{\circ} \mathrm{C}\right)$ di lokasi penelitian, dengan rumus sebagai berikut:

$\operatorname{Ln} M=-0,152-0,279 * \operatorname{Ln} L_{\infty}+0,6543 * \operatorname{Ln} K+0,463 * \operatorname{Ln} T . . .(10)$

Pendugaan mortalitas total (=Z) melalui kurva konversi hasil tangkapan terhadap panjang (length converted catch curve) yang dirunut dengan program FiSAT-II dengan rumus : $\ln =\frac{C(L 1, L 2)}{\Delta t(L 1, L 2)}=c-Z * t\left(\frac{L 1+L 2}{2}\right)$. Ini adalah persamaan linier dimana $y=\ln \frac{C(L 1, L 2)}{\Delta t(L 1, L 2)} ; x=t\left(\frac{L 1+L 2}{2}\right)$ dan slope b adalah $-\mathrm{Z}$. Pendugaan mortalitas karena penangkapan dengan rumus $\mathrm{F}=\mathrm{Z}$ - M. Tingkat pemanfaatan (E) diperoleh dari perbandingan antara nilai $\mathrm{F}$ dengan $\mathrm{Z}$, menggunakan persamaan : $\mathrm{E}=\mathrm{F} / \mathrm{Z}$ (Sparre \& Venema, 1999).

\section{HASIL DAN BAHASAN \\ Hasil}

\section{Distribusi Ukuran Panjang}

Hasil pengukuran panjang total ikan (C.cyanostigma) disajikan ke dalam bentuk grafis (Gambar 1). Panjang ikan C.cyanostigma dari contoh ikan sebanyak 1.946 ekor berkisar antara 15,6 - 38,9 cm TL dengan rata-rata 25,24 $\mathrm{cm}$ TL dan modus pada ukuran panjang $25 \mathrm{~cm}$ sebesar $11,45 \%$ dari total ikan yang diukur. 


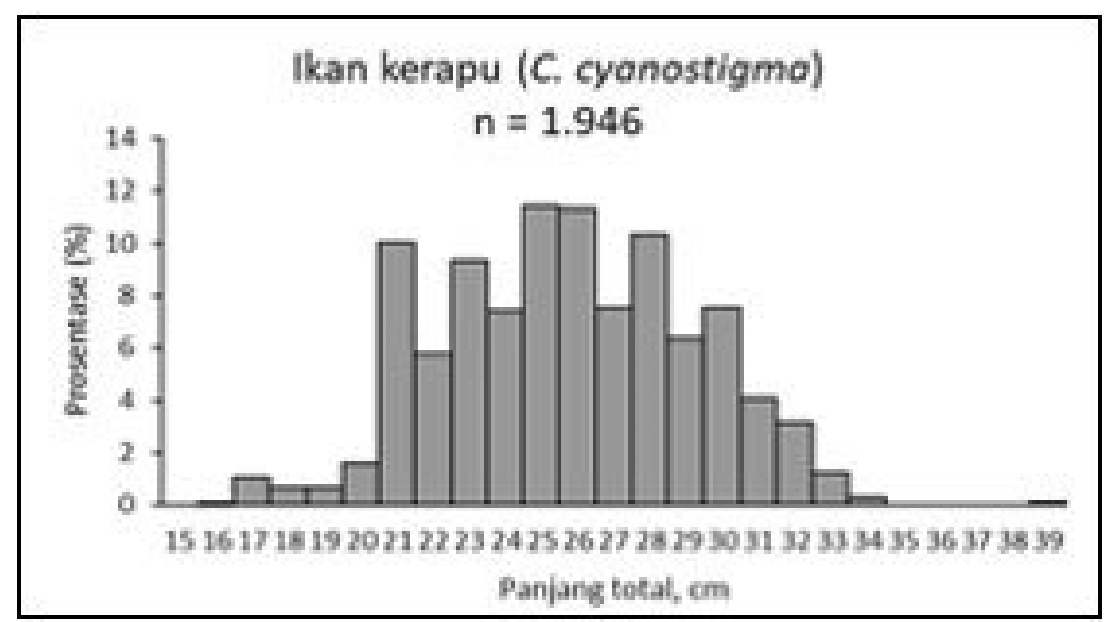

Gambar 1. Distribusi frekuensi panjang kerapu karang bintik biru (C.cyanostigma).

Figure 1. Length frequency distribution of blue spotted hind (C.cyanostigma).

\section{Hubungan Panjang berat}

Persamaan hubungan panjang berat ikan kerapu karang bintik biru (C.cyanostigma) adalah $\mathrm{W}=0,0214 \mathrm{~L}^{2,9184}$ dengan nilai koefesien determinasi $\left(\mathrm{R}^{2}\right)$ sebesar 0,9327. Setelah dilakukan uji-t dengan tingkat kepercayaan $95 \%(\mathrm{a}=0,05)$, didapatkan pola pertumbuhan ikan kerapu karang bersifat issometrik (Gambar 2).

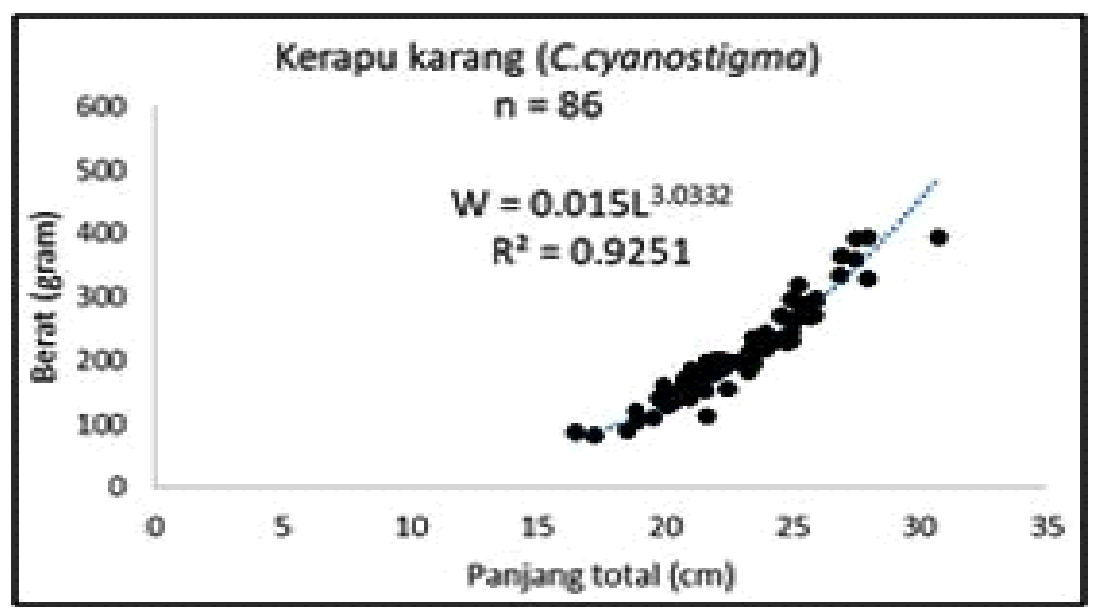

Gambar 2. Hubungan panjang berat ikan kerapu karang (C.cyanostigma) di Karimunjawa.

Figure 2. Length weight relationship of blue spotted hind (C.cyanostigma) in Karimunjawa.

Rata-Rata ukuran pertama kali tertangkap $\left(L_{c}\right)$ dan pertama kali matang gonad $\left(L_{m}\right)$

Hasil analisa data panjang kerapu karang bintik biru dari tangkapan yang didaratkan di Karimunjawa mendapatkan ukuran rata-rata pertama kali tertangkap $\left(\mathrm{L}_{\mathrm{c}}\right)$ untuk tingkat kemungkinan $50 \%$ ikan dewasa tertangkap, yaitu $\mathrm{L}_{\mathrm{c} 50}=24,1 \mathrm{~cm}$ TL (Gambar 3). Hasil pemeriksaan kematangan gonad dan perhitungan menurut prosedur Udupa (1986) mendapatkan ukuran panjang pertama kali matang gonad pada tingkat $50 \%$ populasinya adalah $\mathrm{L}_{\mathrm{m} 50}$ $=21,5 \mathrm{~cm}$ TL. Dengan demikian nilai $\mathrm{L}_{\mathrm{c}}>\mathrm{L}_{\mathrm{m}}$. 


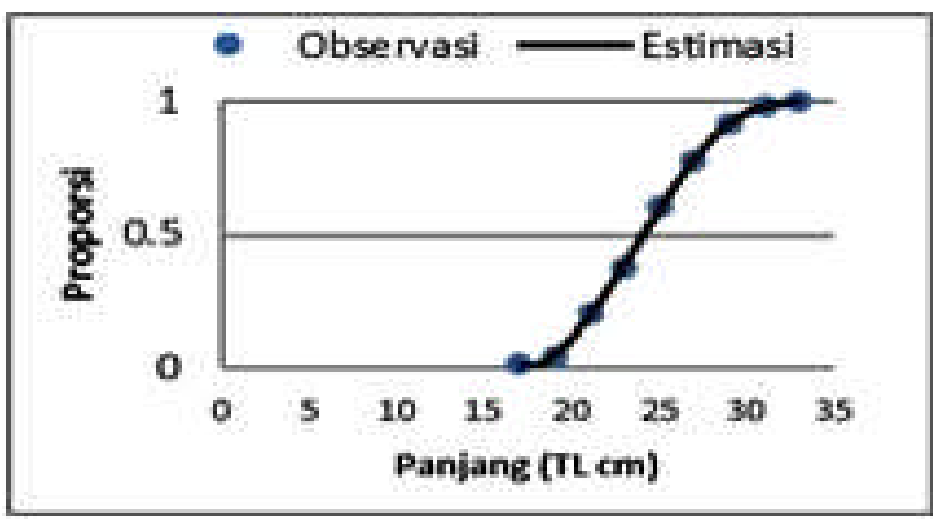

Gambar 3. Panjang rata-rata $\left(\mathrm{L}_{50}\right)$ tertangkap ikan kerapu karang bintik biru di Karimunjawa.

Figure 3. Average length $\left(L_{50}\right)$ of blue spotted hind caught in Karimunjawa.

\section{Estimasi Parameter Pertumbuhan}

Hasil analisa menunjukkan panjang asimptotik $\mathrm{L}_{\infty}=$ $37,29 \mathrm{~cm}$ TL, koefisien pertumbuhan $(\mathrm{K})=0,30$ per tahun dan umur kerapu karang pada saat panjang sama dengan nol $\left(\mathrm{t}_{\mathrm{o}}\right)$ adalah $-0,0429 \mathrm{~cm}$. Pergeseran modus bulanan frekuensi panjang ikan kerapu karang bintik biru disajikan pada Gambar 4.

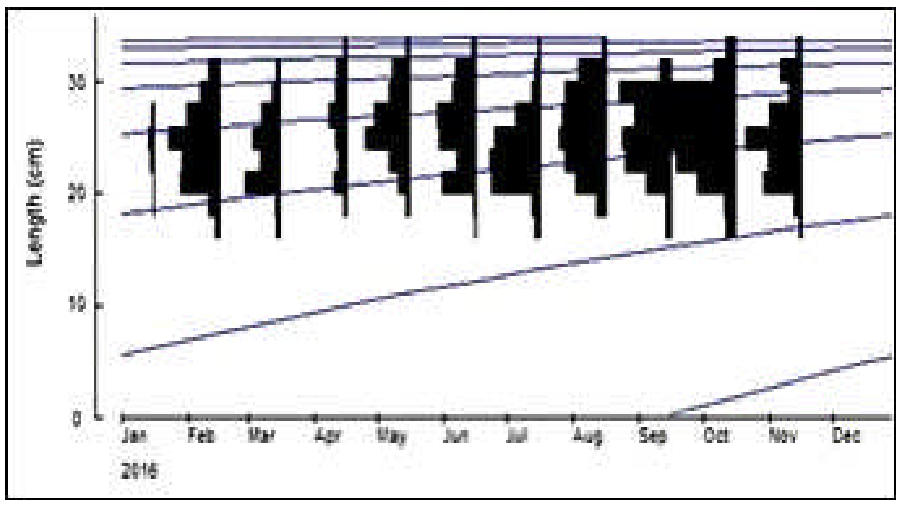

Gambar 4. Sebaran frekuensi panjang kerapu karang bintik biru hasil analisis program ELEFAN.

Figure 4. Length frequency distribution of blue spotted hind resulted from ELEFAN Program analysis.

Dari nilai parameter pertumbuhan tersebut dapat dibentuk persamaan pertumbuhan Von Bertalanffy ikan kerapu karang bintik biru, yaitu $=\mathrm{L}_{\mathrm{t}}=37,29\left(1-\mathrm{e}^{-0,30(\mathrm{t}-0,0429)}\right)$. Dari persamaan ini dapat diperkirakan panjang ikan tersebut berdasarkan pada umur tertentu (Gambar 5). Pendugaan umur secara teoritis ikan kerapu karang bintik biru pada saat $\mathrm{L}_{\mathrm{m}}=21,5$ cmTL adalah 2,85 tahun, pada saat $\mathrm{L}_{\mathrm{c}}=24,1$ $\mathrm{cm}$ diperkirakan berumur 3,45 tahun dan umur ketika mencapai panjang asimptotik ( $\mathrm{L}_{\infty}=37,29 \mathrm{~cm}$ ) adalah diduga berumur 30 tahun.

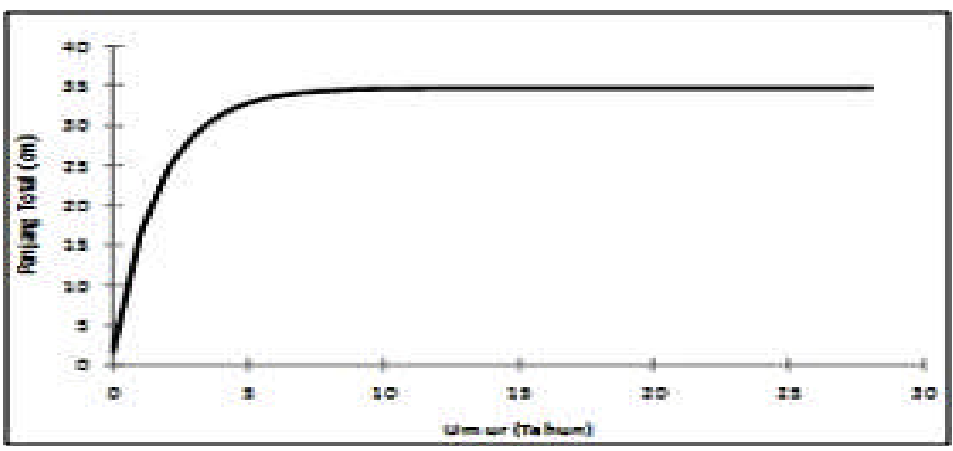

Gambar 5. Kurva pertumbuhan Von Bertalanf fy ikan kerapu karang bintik biru.

Figure 5. Von Bertalanffy growth curve of blue spotted hind. 


\section{Prediksi Laju Kamatian}

Dari parameter pertumbuhan panjang ikan kerapu karang bintik biru yang telah dihitung menurut rumusrumus yang tersedia, laju kematian total didapat, yaitu (Z)
$=1,77$ per tahun, kematian alami $(\mathrm{M})$ sebesar 0,78 per tahun dan nilai tingkat kematian akibat penangkapan $(\mathrm{F})$ sebesar 0,99 per tahun, dan tingkat eksploitasi (E) ikan kerapu tersebut adalah sebesar 0,56 (Gambar 6).

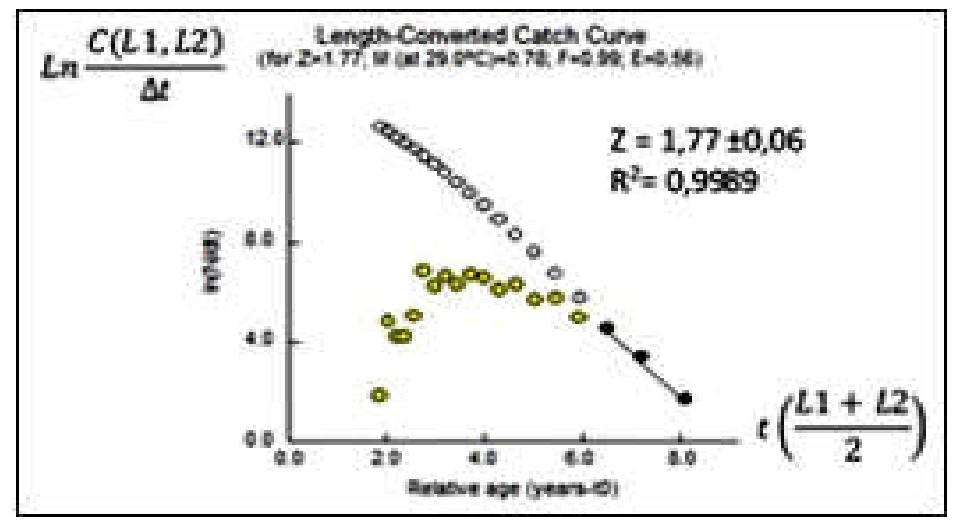

Gambar 6. Nilai Z sebagai fungsi slope kurva hasil tangkapan kerapu karang bintik biru.

Figure 6. The Z-value as function of a fishing slope curve of blue spotted hind.

\section{Bahasan}

Distribusi ukuran panjang ikan C.cyanostigma berkisar antara 15,6 - 38,9 cm TL dengan rata-rata 25,24 cm TL. White et al. (2013) mengatakan panjanag ikan kerapu karang (C.cyanostigma) di Indo Pasifik Barat mencapai $30 \mathrm{~cm}$. Ukuran panjang ikan kerapu karang di perairan Karimunjawa, Jawa Tengah lebih besar dibandingkan ikan kerapu karang (C. cyanostigma) di perairan Great Barrier Reef, Australia berkisar 20,1 - 35,3 cm (Kritzer et al. 2001). Hal ini mengindikasikan bahwa kondisi sumberdaya ikan kerapu karang saat ini lebih baik dibandingkan dengan lokasi lain. Hal ini juga didukung dengan adanya area konservasi di Karimunjawa yaitu Taman Nasional Karimunjawa (TNKJ) sehingga stok ikan kerapu karang dapat terjaga kelestariannya.

Hubungan panjang berat ikan kerapu karang bersifat issometrik yang berarti pertambahan panjang ikan seimbang dengan pertambahan beratnya. Hasil penelitian ini sama dengan hasil penelitian Burton et al. (2015) pada spesies kerapu karang jenis $C$. fulva di perairan Amerika Serikat bahwa pola pertumbuhannya bersifat issometrik. Berbeda halnya dengan hasil penelitian Mapleston et al. (2009) ikan kerapu karang bintik biru (C.cyanostigma) di perairan Great Barrier Reef, Australia bersifat allometrik negative. Menurut Bagenal (1978), faktor-faktor yang menyebabkan perbedaan sifat pertumbuhan ikan adalah jenis kelamin, perbedaan jumlah dan ukuran ikan yang diamati, tahap perkembangan ikan dan faktor lingkungan.

Nilai rata-rata ukuran panjang pertama kali tertangkap $\left(\mathrm{L}_{\mathrm{c}}=24,1 \mathrm{~cm}\right)$ lebih besar dibandingkan dengan nilai ratarata ukuran pertama kali matang gonad $\left(\mathrm{L}_{\mathrm{m}}=21,5 \mathrm{~cm}\right)$. Kondisi ini harus dipertahankan agar populasi ikan kerapu karang dapat terjaga stok nya karena ikan ini tertangkap setelah mengalami proses pemijahan.

Hasil penelitian Longenecker et al. (2011) di Papua New Guinea menemukan bahwa ukuran pertama kali tertangkap $\left(\mathrm{L}_{\mathrm{c}}\right)$ yang diperkirakan $50 \%$ dari kerapu karang bintik biru dewasa adalah $23 \mathrm{~cm}$ TL untuk betina dan 20 $\mathrm{cm}$ TL untuk jantan, tetapi ukuran terkecil matang gonad $\left(\mathrm{L}_{\mathrm{m}}\right)$ adalah $13 \mathrm{~cm}$ TL untuk betina dan $19 \mathrm{~cm}$ TL untuk jantan. Hasil penelitian di Papua New Guinea tersebut menunjukkan $\mathrm{L}_{\mathrm{c}}>\mathrm{L}_{\mathrm{m}}$, dimana hal ini sama dengan hasil penelitian ini di Karimunjawa yang berarti pola penangkapan ikan kerapu karang (C.cyanostigma) dengan menggunakan alat tangkap bubu dan panah belum termasuk kondisi berbahaya $\left(\mathrm{L}_{\mathrm{c}}>\mathrm{L}_{\mathrm{m}}\right)$

Secara umum populasi kerapu karang bintik biru memiliki populasi dengan sebaran frekuensi panjang yang bersifat normal sesuai proporsi umur (Gambar 1). Distribusi frekuensi panjang ikan dari data bulanan memperlihatkan adanya satu kelompok umur (cohort), yaitu sebagai petunjuk terjadinya suatu pertumbuhan ukuran (Gambar 4), dimana pertumbuhan mulai melambat ketika umur dewasa tua (Gambar 5). Hal ini berarti bahwa pola tangkapan mengambil semua kelas umur, dimana kelas umur yang terbanyak tertangkap adalah umur 2,85 tahun, yaitu usia yang termasuk panjang pertama tertangkap $\mathrm{L}_{\mathrm{c}}$ (24,1 cm TL) dan usia ukuran siap panen. Sampel ikanikan muda dengan kisaran panjang $16-20 \mathrm{~cm}$ TL masih dalam proporsi yang rendah dan belum intensif dalam penangkapan, sehingga belum ada tanda-tanda recruitment overfishing, yaitu kelebihan tangkap untuk ukuran ikan muda yang akan menghasilkan kelompok ukuran siap panen berikutnya. Sebaliknya ikan-ikan dewasa dengan ukuran antara 21-30 cm TL, yaitu ukuran 
menjelang matang gonad, sudah masuk pada tanda-tanda penangkapan yang intesif, sehingga mengurangi sediaan ikan-ikan dengan ukuran siap matang gonad

Bentuk pertumbuhan yang terlihat dalam penelitian ini menunjukkan bahwa kerapu karang bintik biru memiliki laju pertumbuhan yang sedikit lebih tinggi dalam perbandingannnya dengan pertumbuhan hasil penelitian Mosse \& Davies, (2007) dan Mapleston et al. (2009) di perairan Great Barrier Reef, Australia (Tabel 1).

Tabel 1. Perbandingan parameter populasi kerapu karang bintik biru dari dua wilayah penelitian

Table 1. Comparetation of blue spotted hind population parameters of two region studies

\begin{tabular}{|c|c|c|c|c|}
\hline \multirow[t]{2}{*}{ Parameter } & \multicolumn{2}{|c|}{$\begin{array}{c}\text { Great Barrier Reef } \\
\text { (Penelitian Mosse \& Davies, 2007) }\end{array}$} & \multirow[t]{2}{*}{$\begin{array}{l}\text { Great Barrier Reef (Penelitian } \\
\text { Mapleston et al. (2009) }\end{array}$} & \multirow{2}{*}{$\begin{array}{l}\text { Karimunjawa } \\
\text { (Penelitian Ini) }\end{array}$} \\
\hline & Orpheus Island & Pelorus Island & & \\
\hline $\mathrm{L} \infty(\mathrm{cm})$ & 25,7791 & 24,4444 & 31,12 & 37,29 \\
\hline $\mathrm{K}$ (per tahun) & 0,22 & 0,25 & 0,040 & 0,30 \\
\hline $\mathrm{t}_{0}$ & $-0,59$ & $-0,41$ & $-27,006$ & $-0,0429$ \\
\hline $\mathrm{N}$ (ekor) & 137 & 121 & 2.607 & 1.946 \\
\hline Kisaran panjang $(\mathrm{cm})$ & $11,4-29,4$ & $12,0-28,5$ & $17,1-42,8$ & $15,6-38,9$ \\
\hline Rata-rata panjang $(\mathrm{cm})$ & 23,08 & 21,895 & & 25,24 \\
\hline Kisaran Umur (tahun) & $2-31$ & $3-23$ & $5-46$ & $2-30$ \\
\hline
\end{tabular}

Hasil penelitian di Karimunjawa menunjukkan panjang asimptotik $\left(\mathrm{L}_{\infty}\right)$ ikan kerapu karang bintik biru sebesar $37,29 \mathrm{~cm}$. Hasil penelitian ini lebih besar dibandingkan dengan hasil penelitian Mosse \& Davies (2007) dan Mapleston et al. (2009) di perairan yang sama yaitu di Great Barrier Reef, Australia. Perbedaan panjang asimptotik $\left(\mathrm{L}_{\infty}\right)$ di perairan Great Barrier Reef, Australia dan Karimunjawa, Indonesia disebabkan oleh selektivitas alat tangkap, lingkungan perairan, perbedaan habitat dan variasi genetik (Heupal et al., 2010).

Laju pertumbuhan (K) ikan kerapu karang bintik biru di Karimunjawa adalah 0,30 per tahun. Nilai K ini lebih besar dibandingkan dengan ikan kerapu karang bintik biru di perairan Great Barrier Reef, Australia berkisar 0,04-0,25 per tahun. Perbedaan dalam koefisien pertubuhan $(K)$ adalah faktor perbedaan dalam hal umur pencapaian panjang asymtotik $\left(\mathrm{L}_{\infty}\right)$ (Gulland, 1983). Perbedaan tersebut disebabkan oleh sifat afinitas yang kuat pada habitat yang menjadi ciri ikan kerapu karang bintik biru (Mackie, 1993), seperti diketahui jenis ini adalah penetap utama di liang karang dan seperti juga genus Cephalopholis spp. yang lain (Shpiegel \& Fishelson, 1989; 1991). Secara geografis, perbedaan relatif dalam kualitas dari habitat setempat, seperti ketersediaan makanan, ruang, adanya predator dan tekanan penangkapan, dapat mempengaruhi pertumbuhan ikan kerapu karang (Watson \& Ormond, 1994). Kecuali itu, perbedaan nilai laju pertumbuhan $(\mathrm{K})$ dari satu species juga menyebabkan perbedaan ukuran pertumbuhan. Nilai K dari kerapu karang bintik biru yang kurang dari satu menunjukkan bahwa ikan ini mempunyai pertumbuhan yang lambat (Gulland, 1983) dan memiliki umur yang relatif panjang (Pauly, 1980).
Laju pertumbuhan yang rendah akan berpengaruh pada pola pemanfaatannya.Untuk tersedianya ukuran rekruitmen siap panen akan membutuhkan waktu yang sedikit panjang. Misalnya, dari ukuran interval $16-18 \mathrm{~cm}$ TL di usia 1 - 2 tahun untuk kemudian tumbuh menjadi menjadi $24-26 \mathrm{~cm}$ TL membutuhkan lebih dari 3 tahun (Gambar 5). Untuk mencapai pola pemanfaatan yang lestari, perlu dipertimbangkan waktu yang tepat untuk menangkap ikan. Terutama perlu adanya pengaturan buka tutup musim panen, sehingga memberi kesempatan pada ikan-ikan yang berumur muda tumbuh dewasa sebelum ditangkap. Menghindari penangkapan ikan-ikan usia muda (nilai Lc $>\mathrm{L}_{\mathrm{m}}$ ) adalah upaya untuk mencegah terjadinya kelebihan tangkap pertumbuhan (growth overfishing) dan sekaligus untuk tetap mempertahankan rekruitmen dalam pengertian manajemen perikanan.

Parameter penting lainnya dalam manajemen perikanan adalah menyangkut laju kematian. Laju kematian ikan Kerapu karang bintik biru, C. cyanostigma, secara alami $(\mathrm{M}=0,78)$ lebih rendah dari laju kematian akibat aktifitas penangkapan $(\mathrm{F}=0,99)$ dan tingkat pemanfaatannya sedikit melebihi optimum (E=0,56). Gulland (1983) menyatakan tingkat pemanfaatan optimum adalah ketika $E=0,5$. Hal ini mengindikasikan bahwa perikanan ikan kerapu karang bintik biru di Karimunjawa saat ini sudah dikelola dengan baik karena adanya daerah konservasi yaitu Taman Nasional Karimunjawa (TNKJ) dan habitatnya cocok untuk ikan kerapu karang bintik biru yang menghuni koloni karang keras diantaranya Pulau Menjangan Besar, Pulau Kumbang, Pulau Kecil dan Pulau Cemara Besar sehingga Karimunjawa menjadi pemasok utama ikan karang untuk Pulau Jawa dan sekitarnya (Mujiono \& Syam 2015). Upaya pengelolaannya adalah tidak menambah upaya penangkapan (unit kapal, trip) dan tetap memperhatikan kehati-hatian panen. 


\section{KESIMPULAN}

Kisaran ukuran ikan kerapu karang bintik biru di perairan Karimunjawa, Jawa Tengah relative lebih besar dibandingkan perairan lain, rata-rata ukuran panjang pertama kali tertangkap (Lc) lebih besar dibandingkan ratarata ukuran panjang pertama kali matang gonad ( $\mathrm{Lm}$ ) dan tingkat pemanfaatannya $(\mathrm{E}=0,56)$ sedikit melebihi optimum yang mengindikasikan stok ikan kerapu karang bintik biru di Karimunjawa dapat terjaga kelestariannya dengan memperhatikan kehati hatian panen.

\section{PERSANTUNAN}

Tulisan ini merupakan kontribusi dari hasil kegiatan Balai Penelitian Perikanan Laut, Jakarta, di Wilayah Karimunjawa yang termasuk WPP 712, T.A. 2016. Penulis mengucapkan penghargaan dan terima kasih atas dukungan kepada Tri Ernawati, M.Si sebagai Penanggungjawab kegiatan penelitian dan enumerator yaitu staf pegawai Pelabuhan Perikanan Pantai Karimunjawa, DKP Prop. Jawa Tengah.

\section{DAFTAR PUSTAKA}

BAKOSURTANAL. (2009). Terumbu karang indonesia (p. 350). Cibinong, Bogor: Pusat Survei Sumber Daya Alam Laut, BAKOSURTANAL.

Burton, M.L. Jennifer C.P., \& Daniel R.C. (2015).

Age, Growth and Natural Mortality of Coney (Cephalopholis fulva) from the Southeastern United States. PeerJ 3.e825. DOI 10.7717/PeerJ.825.

Bagenal T. B. (1978). Ecology of freshwater fish production). Oxford: Balckwell Scientific Publications. p 75-101.

Bryce D. S., \& Beukers, J.S. (2000). Baited technique improves censuses of cryptic fish in complex habitats. Mar Ecol Prog Ser, 197, 259-272. doi: 10.3354/ meps197259.

Cabanban, A.S., Fennessy, S., Myers, R., \& Choat, J.H. (2015). Cephalopholis cyanostigma. The IUCN Red List of Threatened Species 2008: e.T132808A3457113. (10 pp.). Http://dx.doi.org/10.2305/IUCN.UK. 2008.RLTS. T132808A3457113.en

Choat, J.H., Craig, M., \& Ferreira, B. (2008). Variola louti. The IUCN Red List of Threatened Species 2008: e.T132738A3437243. http://dx.doi.org/ 10.2305/ IUCN.UK.2008. RLTS. T132738A3437243.en.

Effendie, M. I. (2002). Biologi Perikanan (Revisi) (p. 163). Bogor: Yayasan Pustaka Nusatama.
Gulland, J. A. (1983). Fish stock assessment. A Manual of Basic Methods. (p. 223). Chichester, U.K. : John Wiley \& Sons Ltd.

Heupel, M. R., Williams, A. J., Welch, D. J., Davies, C. R., Penny, A., Kritzer, J. P., Mapstone, B. (2010). Demographic characteristics of exploited tropical lutjanids/ : a comparative analysis. Fish. Bull, 108, 420432.

Holden, M.J., \& Raitt, D.F.S. (1974). Manual of fisheries science. Methods of resources investigation and their application, Part 2. FAO Fish Tech. Pap. 115: p 214.

Irnawati, R., Simbolon, D., Wiryawan, B., Murdiyanto, B., \& Nurani, T.W. (2012). Model pengelolaan perikanan karang di Taman Nasional Karimunjawa. Forum Pascasarjana, 35(1), 25-35.

Kritzer, J.P., C.R. Davies, C.R. \& B.D. Mapstone. 2001. Characterizing fish populations: effect of sample size and population structure on the precision of demographic parameter estimates. Can. J. Fish. Aquat. Sci. vol.58. 1557-1568. DOI. 10.1139/CJFAS-58-8-1557.

Longenecker, K., Langston, R., Bolick, H., \& Kondio, U. (2011). Reproduction, Catch, and Size Structure of Exploited Reef-Fishes at Kamiali Wildlife Management Area, Papua New Guineaa. Bishop Museum Technical Report 57 (171 pp.). Honolulu, Hawaii: Bishop Museum Press.

Mackie, M. (1993). Reproductive biology and social structure of the blue-Spot rock cod, Cephalopholis cyanostigma (Serranidae), and the effects of fishing. BSc (Hons) thesis, James Cook University, Townsville.

Mapleston, A., Currey,L.M., A.J. Pears, R., Simpfendorfer, C.A. Penny, A.L., Tobin,A. \& Welch, D. (2009). Comparative biology of key inter-reefal serranid species on the Great Barrier Reef. Project Milestone Report to the Marine and Tropical Sciences Research Facility. Reef and Rainforest Research Center Limited, Caims (155pp).

Mosse, J.W. (2001). Population biology of Cephalopholis cyanostigma (Serranidae) of the Great Barrier Reef, Australia. PhD thesis, James Cook University, Townsville.

Mosse, J.W., \& Davies, C.R. (2007). The extended longevity of small coral reef serranid: a lesson from Cephalopholis cyanostigma (Blue spot rock cod) of the Central Great Berrier Reef, Autralia. Mar. Res. Indonesia, 32 (1), 21 - 33. DOI: https://doi.org/ $\underline{10.14203 / \mathrm{mri} . v 32 \mathrm{i} 1.428}$ 
Mujiyanto \& Syam, A.R. (2015). Karakteristik habitat kerapu di Kepulauan Karimunjawa, Jawa Tengah. BAWAL, 7(3), 147-154. DOI: http://dx.doi.org/10.15578/ bawal.7.3.201.147-154

Pauly, D. (1980). A selection of simple methods for the assessment of tropical fish stocks. (p.54). Roma, Italy: FAO Fish. Circ. FIRM/C 729.

Pelabuhan Perikanan Pantai Karimunjawa. (2016). Data statistik perikanan 2014, 2015 dan 2016. Karimunjawa, Jepara: DKP Propinsi Jateng.

Ruchimat, T., Basuki, R., \& Suraji. (2012). Kawasan Konservasi, Perairan, Pesisir dan Pulau-Pulau Kecil: Paradigma, Perkembangan dan Pengelolaannya. (105 hal). Jakarta, Indonesia: Dirjen KP3K- KKP - Dir. KKJI Publ.

Shpiegel, M., \& Fishelson, L. (1989). Food habits and prey selection of three species of groupers from the genus Chepalopholis. Env. Biol.Fish, 24(1), 67-73.

Shpiegel, M. \& Fishelson, L. (1991). Experimental removal of piscivorous groupers of genus Cephalopholis (Serranidae) from coastal habits in the Gulf of Aqaba (Red Sea). Env. Biol. Fish. 31, 131-138.
Sparre, P., \& Venema, S.C. (1999). Introduksi pengkajian stok ikan tropis. Buku 1. Manual. (438 pp). Terj. Puslitbang Perikanan. Jakarta, Indonesia: FAO/ DANIDA.

Udupa, K.S. (1986). Statistical method of estimating the size of first maturity in fish. Fishbyte ICLARM.Manila. $4(2), 1-8$.

Watson, M. \& Ormond, R.F.G. (1994). Effect of an artisanal fishery on the fish and urchin population of Kenyan coral reef. Mar.Ecol.Prog.Ser. 109, 15-29.

White, W.T., Last, P.R., Dharmadi, Faizah, R., Chodrijah, U., Prisantoso, B.I., Pogonoski, J.J., Puckridge, M., Blader, S.J.M. (2013). Market fishes of Indonesia (Jenis jenis ikan di Indonesia). Canberra. ACIAR Monograph N0. 155.

Zeller, D., Stoute, S.L., \& Russ, G.R. (2003). Movements of reef fishes across marine reserve boundaries: effects of manipulating a density gradient. Mar Ecol Prog Ser. (254), 269-280. DOI: 10.3354/meps254269. 
Lampiran 1. Kriteria tingkat kematangan gonad Appendix 1. Criteria of gonad maturity stages

\begin{tabular}{|c|c|c|}
\hline $\begin{array}{c}\text { Stadium/ } \\
\text { Stages }\end{array}$ & $\begin{array}{c}\text { Status/ } \\
\text { Conditions }\end{array}$ & Keterangan/Remarks \\
\hline $\mathrm{I}$ & $\begin{array}{l}\text { Belum Matang/ } \\
\text { Immature }\end{array}$ & $\begin{array}{l}\text { Ovari dan testes kira2 } 1 / 3 \text { panjang rongga badan. Ovari } \\
\text { berwarna kemerah-merahan bening. Testes berwarna } \\
\text { keputih-putihan. Telur tidak terlihat dengan mata telanjang }\end{array}$ \\
\hline II & $\begin{array}{l}\text { Perkembangan } \\
\text { Developing }\end{array}$ & $\begin{array}{l}\text { Ovari dan testes kira } 21 / 2 \text { panjang rongga badan, bening atau } \\
\text { jernih. Testes keputih-putihan, kurang lebih semetris. Telur } \\
\text { tidak terlihat dengan mata telanjang }\end{array}$ \\
\hline III & $\begin{array}{l}\text { Pematangan/ } \\
\text { Ripening }\end{array}$ & $\begin{array}{l}\text { Ovari dan testes kira } 2 \text { 2/3 panjang rongga badan. Ovari } \\
\text { berwarna kemerah-merahan dan butiran telur mulai jelas. } \\
\text { Testes berwarna keputih-putihan sampai krem. Tidak ada } \\
\text { telur yang tembus cahaya atau jernih. }\end{array}$ \\
\hline IV & $\begin{array}{l}\text { Matang/Ripe } \\
\text { Or Fully Mature }\end{array}$ & $\begin{array}{l}\text { Ovari dan testes kira2 } 2 / 3 \text { panjang rongga badan. Ovari } \\
\text { berwarna orange dengan pembuluh darah terlihat jelas di } \\
\text { permukaannya. Terlihat telur yng masak dan tembus cahaya. } \\
\text { Testes berwarna keputih-putihan sampai krem dan lembut. }\end{array}$ \\
\hline V & $\begin{array}{l}\text { Mijah Salin/ } \\
\text { Spent }\end{array}$ & $\begin{array}{l}\text { Ovari dan testes mengerut sampai menjadi kira-kira } 1 / 2 \text { rongga } \\
\text { badan. Dinding-dinding mengendur. Ovari dapat } \\
\text { mengandung sisa-sisa telur. }\end{array}$ \\
\hline
\end{tabular}

Sumber/Source: Holden \& Raitt (1974) 